the important relationship between termites and fungi covers its behavioural, nutritional and evolutionary aspects. The final chapter, by Kistner, on the biology and phylogeny of termitophile staphylinids, looks sympathetically, though critically, at explanations of the behavioural basis of this relationship.

The book has a good index and is well, though not exceptionally well, illustrated. Its informative and stimulating treatment of termite biology will rightly earn it a place in zoological libraries.

J. H. SUDD

\section{Dr C. L. Smith}

CyriL (Charles) Leng Smith, who died on July 11, aged 65, was educated at Jincoln City School and went to Cambridge with a scholarship at Sidney Sussex College. He studied both physical and biological sciences and began his research career under Rutherford at the Cavendish Laboratory. During the early years of the Second World War Smith did pioneer work on ground and airborne radar and was later awarded an MBE for this work. In 1944 ho returned to the Cavendish Laboratory and worked on plastic flow of metals and single crystals.

In 1949 he joined the university departmont of radiotherapeutics at Cambridge, as a colleague of Professor J. S. Mitchell, and worked actively in this field until his death. After an early interest in the effect of radiation on enzymes, Smith became well known for his work on the development of techniques for microbeam irradiation of small parts of single cells. His experiments with the microbeam were primarily concerned with the mechanism of mitosis and DNA synthesis in mammalian cells. During this period he worked in the biophysics division at Yale University for a year as Higgins Research Fellow. He was for a time director of studies in physics at St Catharine's College, Cambridgo, and in 1960 was elected to a fellowship at St John's College.

In addition to his research work, Smith was Secretary of the University Committee on Precautions in the use of Radioactive Materials, a member of the Government Managing Sub-Committee on Monitoring of Fall Out in Food, etc., Treasurer of the International Congress of Radiation Research (1962), and Joint Organizing Chairman of a NATO Summer School on Microbeam and Partial Coll Irradiation (1967). He will be particularly remembered by his younger research colleagues for his encouragement and efforts to ensure their full participation.

\section{University News}

Professor M. G. Smith, University of California, has been appointed to the chair of anthropology tenable at University College, University of London.

The title of professor of geography has been conferred on Dr T.J. Chandler in respect of his post at University College, University of London.

The title of professor of theoretical physics has been conferred on Dr E. H. Hutten in respect of his post at Royal Holloway College, University of London.

The title of professor of experimental pathology has been conferred on Dr D. A. Willoughby in respect of his post at St Bartholomew's Hospital Medical School, University of London.

\section{Appointments}

Dr P. L. Bender, Astrophysics Division of the National Bureau of Standards and Department of Physics and Astrophysics in the University of Colorado, has been elected chairman of the Joint Institute for Laboratory Astrophysics. The Joint Institute was established in 1962 as a collaborative effort of the University of Colorado and the National Bureau of Standards.

\section{Announcements}

The council of the Royal Geographical Society has awarded a special gold Moon Medal to Mr Neil Armstrong, leader of the Apollo 11 expedition.

Erratum: In the article "Natural Calcium Oxalate with Heavy Carbon" by J. Hoefs (Nature, 223, 396; 1969), "between 20 per cent and 30 per cent" should be changed to "between 20 and 30 parts per thousand" in line 31 of the text.

\section{International Meetings}

September 2-5, Bird Hazards to Aircraft, Ontario (Mr M. K. Ward, Conference Secretary, National Research Council of Canada, Ottawa, Ontario, Canada).

September 2-6, Seventh International Pigment Cell Conference, Seattle (Dr V. Riley, Conference Chairman, Pacific Northwest Research Foundation, 1102 Columbia Street, Seattle, Washington 98104, USA).

September 3-11, 37th Session of the International Statistical Institute, London (Secretary, Organizing Committee, 37th Session of the ISI, Conference Centre, 43 Charles Street, London WI).

September 9-10, Technological Forecasting-Some Techniques, Birmingham (C. Hearn Buck, Design and Innovation Group, University of Aston in Birmingham, Birmingham 4, UK).

September 15-17, Advances in Polymer Blends and Reinforcements, Loughborough (R. H. Craven, the Institution of the Rubber Industry, 4 Kensington Palace Gardens, London W8).

September 15-17, 6th World Orchid Conference, Sydney (Dr Keith Kirkland, Wentworth Hotel, Sydney, Australia).

September 15-17, Psychology of Sport, Lausanne (Dr E. de Winter, Société Française de Psychologie dess Sports, 185 Avenue Victor-Hugo, Paris, France).

September 16-18, Industrial Applications of Dynamic Modelling, Durham (Manager, Conference Department, Institution of Electrical Engineers, Savoy Place, London WC2).

September 19-20, Materials in Leisure and Sport, Worcester (Mr M. G. Bader, Department of Metallurgy and Materials Tcchnology, University of Surrey, Guildford, Surrey, UK).

September 22-23, The Use of Cyclotrons in Chemistry, Metallurgy and Biology, Oxford (F. K. Pyne, Conference Secretary, Atomic Energy Establishment, Harwell, Didcot, Berkshire, UK).

September 22-24, Condensation and Ice Nuclei, Vienna (Dr H. K. Weickmann, e/o Atmospheric Physics and Chemistry Laboratory, ESSA, Department of Commerce, Boulder, Colorado 80302, USA). 